\title{
Pengaruh Pola Asuh Orang Tua Terhadap Pembentukan Karakter Remaja Usia 13-18 Tahun Di Gereja Sidang Injil Broneo Long Tuan Sarawak Malaysia
}

\author{
Robina Paru, Ivan Th. J. Weismann
}

\begin{abstract}
Abstrak
Penulisan skripsi ini bertujuan untuk mengetahui bagaimanakah pola asuh yang diterapkan oleh orang tua, seberapa besarkah pengaruhnya terhadap pembentukan karakter remaja di jemaat SIB Long Tuan. Pola asuh orang tua dapat didefinisikan sebagai cara merawat, membimbing dan memimpin seorang anak dalam keluarga. Dengan adanya pola asuh maka akan memenuhi kebutuhan si anak karena pola asuh yang terapkan ke dalam keluarga merupakan pendidikan pertama yang anak-anak dapat pelajari dalam kehidupannya. Di lihat dari bentuknya dan penerapanya pola asuh orang tua dapat dibagi menjadi tiga, yakni permisif, otoriter dan demokratis. Sedangkan pengertian karakter adalah watak, tabiat dan sifat. Karena orang tua merupakan pendidik utama dan pertama dalam keluarga maka pembentukan karakter remaja sangatlah dipengaruh pola asuh orang tuanya, baik dari segi positif dan negatif. Jadi penulis telah melaksanakan penelitian ini di Gereja Sidang Injil Broneo Long Tuan, di tempat asal penulis sendiri. Cara penelitian yang digunakan adalah wawancara dengan menggunakan angket/kuesioner. Hasil penelitian dibuat bahwa pola asuh orang tua yang diterapkan dalam mengasuh anak mereka yaitu pola asuh demokratis sehingga membentuk karakter remaja.
\end{abstract}

Kata kunci: Pola Asuh, Orang Tua, Karakter, Remaja.

\section{Pendahuluan}

\section{Latar Belakang Masalah}

Remaja adalah golongan pribadi yang sedang mengalami perkembangan secara fisik, emosi, sosial, mental dan kerohanian. Dimana usia ini masih berjuang dengan kemampuan diri sendiri demi memahami identitas dan tujuan keberadaan hidupnya secara keseluruhan, terutama dengan banyak hal yang sedang terjadi dimasa-masa modern ini. Menurut Syamsu Yusuf "Remaja sebagai individu sedang berada dalam proses berkembang atau menjadi (becoming), yaitu berkembang ke arah kematangan atau kemandirian. Untuk mencapai kematangan tersebut, remaja memerlukan bimbingan karena mereka masih kurang memiliki pemahaman atau wawasan tentang dirinya dan lingkungannya, juga pengalaman dalam menentukan arah kehidupannya."1

\section{9.}

\footnotetext{
${ }^{1}$ Syamsu Yusuf, Psikologi Perkembangan Anak dan remaja (Bandung: Remaja Rosdakarya, 2016),
} 
Oleh karena itu, hal yang perlu diperhatikan oleh orang tua sebelum anaknya mencapai usia remaja, orang tua hendaklah memberi didikan kepada anak pada usia dini atau kanak-kanak dengan bertujuan untuk membentuk karakter anak tersebut. Ini merupakan dasar yang penting bagi pertumbuhan dan perkembangan kepribadian seorang anak. "Seorang ibu yang melahirkan anak pasti ingin mengetahui seperti apa dan bagaimanakah anaknya suatu saat nanti, pertanyaan ini merupakan rentang waktu yang sangat panjang dan sulit untuk diramalkan tentang keadaan anak itu kelak."2 Seorang anak yang dilihat bagaimana dan seperti apakah anak itu kelak akan dilihat dari pembentukan lingkungannya dimana anak itu berada. "karena perilaku seseorang adalah hasil interaksi antara dirinya dengan lingkungan, perilaku harus dipelajari dalam hubungan dengan lingkungannya." 3 Jadi orang tua haruslah menciptakan suatu kehidupan yang dapat memperkuatkan apa yang sudah diajarkan kepada anak.

Keluarga atau orang tua yang melakukan peran dan tanggungjawab dalam mengasuh anak sangat membantu pembentukan karakter anaknya dalam masa memasuki usia remaja. Y.Bambang Mulyono mengatakan "pada masa remaja, dapat dikatakan seseorang mengalami perkembangan yang khusus. Dalam perkembangan itu, seorang remaja berada dalam masa peralihan, yaitu perkembangan dari seorang anak menjadi seorang dewasa."4 Masa perkembangan anak remaja, orang tua harus peka dan memahami akan perubahan tersebut.

Orang tua yang mengambil peran tentang perubahan-perubahan yang akan terjadi pada anak remaja hendaklah berorientasi kepada kebutuhan anak sebagai makluk yang perlu perhatian serta menggunakan cara-cara yang sesuai dengan perkembangan dan pertumbuhan dalam kehidupan seorang anak remaja. Di sini orang tua perlu memilih pola asuh yang tepat untuk membimbing anak remaja, karena apabila orang tua menerapkan hal-hal yang positif dalam pola asuh maka sikap tersebut akan tertanam di dalam hati remaja tersebut.

Bill Sanders mengatakan:

Jika anda memberi dorongan kepada putra atau putri anda, maka ia akan bertumbuh sebagai seorang yang memberi dorongan kepada orang lain. Jika anda mengkritik anakanak anda, mereka akan menjadi seorang yang suka mengkritik orang lain, jika anda suka memaki-maki orang di belakang mereka, anda akan melihat bahwa mereka pun melakukan hal yang sama terhadap orang lain. Pendeknya apapun yang anda lakukan, mereka pun akan melakukannya juga. ${ }^{5}$

Dapat dikatakan dari kutipan di atas bahwa tindakan-tindakan yang dilakukan oleh orang tua dalam pola asuhnya sangat mempengaruhi kepribadian seorang anak, sementara anak itu sudah mencapai usia remaja ini akan menyebabkan remaja tersebut dapat bertindak dalam hal yang positif dan negatif terhadap orang lain bahkan kepada orang yang ada didalam keluarganya sendiri.

Oleh yang demikian, keadaan yang dihadapi anak remaja sehingga menghambat perkembangan karakter adalah tergantung pada lingkungan keluarga dimana suasana keluarga yang baik akan mencurahkan kasih sayang, perhatian dan bimbingan namun

\footnotetext{
${ }^{2}$ Singgih Gunasa dan Yulia Singgih Gunasa, Psikologis Praktis Anak, Remaja dan Keluarga (Jakarta: BPK Gunung Mulia, 2011), 91.

${ }^{3}$ Singgih D. Gunasa dan Yulia Singgih D. Gunasa, Psikologis Praktis Anak, Remaja dan Keluarga (Jakarta: BPK Gunung Mulia, 2011), 1.

${ }^{4}$ Y. Bambang Mulyono, Kenakalan Remaja (Yogyakarta: ANDI Ofset, 1986), 9.

${ }^{5}$ Bill Sanders, Dari Remaja Untuk Orang Tua (Bandung: Kalam Hidup, 1987), 50.
} 
sebaliknya keluarga yang kurang harmonis bersikap keras dan kurang mementingkan nilai agama akan menghalangi pembentukan yang baik pada kepribadian anak.

Melalui observasi dan wawancara penulis kepada pembina remaja di Gereja Sidang Injil Borneo Long Tuan, di tempat asal penulis. Bahwa masalah yang dihadapi oleh beberapa remaja pada usia 13-18 tahun dimana mereka mengalami hambatan dalam perkembangan dan pembentukan karakter, dimana pada pada usia 13-15 tahun mereka bersikap pemalu dan tidak ingin menonjolkan diri meskipun usia ini dikatakan setia mengikut kegiatan rohani sedangkan pada golongan usia 16-18 tahun menurut pembina remaja, usia ini mulai matang secara kepribadian namun mulai menghindarkan diri dari kegiatan rohani khususnya para laki-laki ada beberapa yang beralasan orang tuanya tidak memberi teladan dan kasar dan juga ada yang senang mengikuti teman sebaya yang seusianya.

\section{Pokok Masalah}

Dengan latar belakang masalah di atas ini, maka yang menjadi pokok masalah dalam penulisan karya ilmiah ini adalah sejauh mana pengaruh pola asuh orang tua terhadap pembentukan karakter remaja umur 13 - 18 tahun di Gereja SIB Long Tuan Sarawak, Malaysia.

\section{Tujuan Penelitian}

Adapun tujuan yang dicapai dalam penulisan karya ilmiah ini adalah menjawab permasalahan yang telah dirumuskan yaitu untuk menganalisis pengaruh pola asuh orang tua terhadap pembentukan karakter remaja umur 13-18 tahun di gereja SIB Long Tuan, Sarawak, Malaysia.

\section{Manfaat Penelitian}

Dalam penulisan skripsi ini, manfaat yang dapat diperoleh adalah:

Pertama, sebagai salah satu persyaratan dalam menyelesaikan pendidikan strata satu di Sekolah Tinggi Theologia Jaffray, Makassar.

Kedua, melalui penulisan ini orang tua mampu menyadari dan menerapkan pola asuh dan terlibat aktif terhadap pembentukan karakter anak remaja.

Ketiga, sebagai bahan evaluasi bagi Gereja Sidang Injil Borneo Long Tuan Sarawak, Malaysia untuk kemajuan pelayanan.

Keempat, sebagai bekal penulis untuk mempersiapkan diri masuk ke dalam pelayanan ketika dipercayakan-Nya.

\section{Metode Penelitian}

Adapun metode penelitian yang dipakai dalam penulisan karya ilmiah ini adalah metode kuantitatif dengan menggunakan teknik analisis data menggunakan metode observasi, wawancara (angket $)^{6}$ dan dokumen di samping itu penulis juga menggunakan studi kepustakaan yang meliputi buku-buku yang berkaitan dengan judul karya ilmiah ini.

\footnotetext{
${ }^{6}$ Hengki Wijaya, ed., Metodologi Penelitian Pendidikan Teologi (Makassar: Sekolah Tinggi
} Theologia Jaffray, 2016), 69-73. 


\section{Batasan Penelitian}

Penulis menyadari bahwa penelitian mengenai pola asuh orang tua sangatlah luas, jadi untuk untuk menjaga agar tulisan ini terarah maka penulis membatasi ruang lingkup Kajian Pola Asuh Orang Tua Terhadap Pembentukan Karakter Remaja usia 13-18 tahun di Gereja SIB Long Tuan.

\section{Kesimpulan}

Berdasarkan penelitian yang telah dilakukan tentang Pengaruh Pola Asuh Orang Tua Terhadap Pembentukan Karakter Remaja umur 13-18 Tahun di Gereja Sidang Injil (SIB) Long Tuan Sarawak Malaysia. Maka dapat disimpulkan sebagai berikut:

Dari hasil angket tersebut yang penulis dapat lihat bahwa pola asuh yang orang tua terapkan dalam mengasuh anak mereka sehingga membentuk karakter remaja di gereja SIB Long Tuan adalah pola asuh demokratis dimana pola asuh ini sangat dominan atau menonjol dalam didikan mereka, meskipun terdapat pola asuh otoriter dan permisif tetapi itu hanya diterapkan pada waktu tertentu saja sesuai dengan keadaan dan kebutuhan anak tersebut. Dari cara pengasuhan kepada anak remaja, orang tua mementingkan kebutuhan baik secara fisik, mental, moral dan rohani maupun sosial. Dalam hal itu orang tua tidak mengekang remaja namun sering memberi perhatian. Namun pun demikian orang tua juga tidak terlalu memberi kebebasan tetapi ada batas-batas tertentu yang orang tua terapkan sesuai keadaan anak remaja tersebut.

Adapun yang keadaan yang membuat anak salah dalam bertindak adalah karena pengaruh dari teman sebaya dan media sosial dan kemungkinan besar terjadi dari dalam keluarga oleh karena tidak ada dukungan dari orang tua dimana ada ketidaksesuaian antara apa yang diajar atau dituntut orang tua terhadap anak, dengan melihat apa yang dilihat oleh anak itu sendiri dari kehidupan orang tuanya, dapat menimbulkan konflik dalam diri si anak, pengaruh yang seperti inilah yang sering kali tidak disadari oleh sebagian orang tua.

\section{Kepustakaan}

Amirulloh, H. Teori Pendidikan Karakter Remaja Dalam Keluarga. Bandung: Alfabeta, 2015.

Asrori, M., Ali Mohammad. Perkembangan Remaja: Perkembangan

Remaja:Perkembangan Peserta Didik. Jakarta: PT Bumi Aksara, 2016.

Atiyanto, Srididi. Kebutuhan Manusia, Persoalan Dan Pencengahnya. Bandung: Lembaga Literatur Baptis, 1980.

Backus, C., William. Menjadi Orang Tua Yang Berwibawa. Jakarta: Yayasan Pekabaran Injil,1995.

Beers, Gilbert V. Orang Tua, Bebicaralah Dengan Anak Anda!. Bandung: Kalam Hidup, 2003.

Brewster, Dan. Children \& Childhood In The Bible. Kanada: Compassion Internasional, 2011.

Burrows, D., Munroe Myles. Kingdom Parenting. Jakarta: Immanuel, 2002. 
Dobson, James. Menjelang Masa Remaja. Jakarta: BPK Gunung Mulia, 1983.

Perkembangan Remaja Dan Anak. Departemen Pendidikan Dan Kebudayaan Direktorat Jeneral Pendidikan Tinggi Proyek Normalisasi kehidupan Kampus, 1979.

Eyre, R., Linda. Mengajarkan Nilai-Nilai Kepada Anak. Jakarta: PT Gramedia Pustaka Utama, 1999.

Gunarsa, Yulia Singgih D., Singgih D. Gunarsa. Psikologis Perkembangan Anak \& Remaja. Jakarta: BPK Gunung Mulia, 2017.

Hasbulah. Dasar-Dasar Ilmu Pendidikan. Jakarta: PT RajaGrafindo Persada, 2015

Herman, K., Catherine Wegner dan Paul. Wise Parenting. Jakarta: Immanuel, 2016.

Huriah, Rachmah. "Nilai-Nilai Dalam Pendidikan Karakter Bangsa Yang Berdasarkan

Pancasila dan UUD 1945." E-Journal Widaya Non-Eksakta 1, No. 1 (Juli-Desember 2013): 7-14. Diakses 17 Februari 2018.

http://ejournal.jurwidyakop3.com/index.php/ejournal noneksakta/article/viewFile/134/117.

Jannah, Husnatul. "Bentuk Pola Asuh Orang Tua Dalam Menanamkan Perilaku Moral Pada Anak Usia Di Kecamatan Ampek." Jurnal Ilmiah Pesona Paud 1, No. 1 (2012): 1-9. Diakses 26 Oktober 2017. http://ejournal.unp.ac.id/index.php/paud/article/viewFile/1623/1397.

Kurniawan, Syamsul. Pendidikan Karakter: Konsepsi \& Imyplementasinya secara terpadu lingkungan keluarga, Sekolah, Perguruan Tinggi, Masyarakat. Yogyarkarta ArRuzz Media, 2013.

Kenny, M., Kenny James. Dari Bayi Sampai Dewasa. Jakarta: BPK Gunung Mulia, 1988.

Lestari, Sri. Psikologi Keluarga: Penanaman Nilai \& Penanganan Konflik dalam Keluarga. Jakarta: Prenada Media Group, 2016.

Lewis, Paul. Cara Mengarahkan Anak. Bandung: Yayasan Kalam Hidup, 2005.

Laufer, Rut. Pedoman Pelayanan Remaja. n.p: Batu, 1990.

Luneto, B., Pantu Ayuba. "Pendidikan Karakter dan Bahasa.”Jurnal Al-Ulu

14, No. 1 (Juni 2014): 153-170. Diakses 16 Februari 2018.

https://media.neliti.com/media/publications/217421-pendidikan-karakter-danbahasa.pdf.

MacArthur, John. Kiat Sukses Mendidik Anak Dalam Tuhan. Jakarta: Immanuel, 2005.

Maruanaya, Vita, DAN Weismann, Ivan. "Peran Orang Tua Terhadap Perkembangan Pribadi

Remaja Atas Pemanfaatan Internet di Kalangan Remaja di SMU Advent

Makassar" Jurnal Jaffray [Online], Volume 8 Nomor 1 (1 April 2010).

Mulyono, Bambang Y. Kenakalan Remaja. Yogyakarta: ANDI OFFSET, 1986.

Ndraha, T., Ndraha Roswitha dan Simanjuntak Julianto. Merekayasa Lingkungan Anak. Bandung: Kalam Hidup, 2014.

Otis, Don S. Membina Anak Bermoral. Bandung:Yayasan Kalam Hidup, 2003.

Santrock, John W. Adolescence Perkembangan Remaja. Jakarta: Erlangga, 2003.

Sanders, Bill. Dari Remaja Untuk Orang Tua. Bandung: Kalam Hidup,1987.

Santoso, Budiarti M., Humaedi Sahadi, Dadan Sumara. "Kenakalan Remaja Dan

Penanganannya." Jurnal Penelitian \& PMM 4, No. 2 (Juli 2017): 129-389. Diakses 2

Juni 2018. http://jurnal.unpad.ac.id/prosiding/article/view/14393.

Saripudin, D., Komalasari Kokom. Pendidikan Karakter. Bandung: Refika 
Aditama 2017.

Setiawani, Mary Go. Menerobos Dunia Anak. Bandung: Kalam Hidup, 2004.

Sherlly Allen Judith. Kebutuhan Rohani Anak. Bandung: Kalam Hidup, 1982.

Sholeh, M., Ahmadi Abu. Psikologis Perkembangan. Jakarta: PT Rineka Cipta, 2005

Suyitno, Imam. "Pengembangan Pendidikan Karakter dan Budaya Bangsa

Berwawasan Kearifan Lokal.”Jurnal Pendidikan Karakter I, No. 1 (Februari

2012): 1 - 13. Diakses 16 Februari 2018.

https://www.researchgate.net/profile/Imam_Suyitno/publication.

Gunarsa, D. Singgih. Dari Anak Sampai Usia Lanjut. Jakarta: BPK Gunung Mulia, 2006.

Sidjabat, B. S. Membesar Anak Dengan Kreatif. Yogyakarta: ANDI, 2012.

Simantunjak, J., Ndraha Roswitha. Tidak Ada Anak Yang Suli. Yogyakarta:

ANDI, 2013.

Smith, Fred. Memimpin Dengan Integritas. Jakarta: Immanuel Yayasan Pekabaran Injil, 2002.

Surbakti, Elisa B. Konseling Praktis:Mangatasi Berbagai Masalah. Bandung: Kalam

Hidup, 2008.

Swindoll, C., Susie, Wiriadinata. Anda dan Anak. Surabaya: YAKIN, n.d.

Tomatala, Yakob. Pemimipin Yang Handal. Jakarta: YT Leadership Foundation, 1996.

Wadi, Elsyana, DAN Selfina, Elisabet. "Peran Orang Tua Sebagai Keluarga Cyber Smart

Dalam Mengajarkan Pendidikan Kristen Pada Remaja GKII Ebenhaezer Sentani

Jayapura Papua" Jurnal Jaffray [Online], Volume 14 Nomor 1 (14 Maret 2016).

Wijaya, Hengki (ed.). Metodologi Penelitian Pendidikan Teologi. Makassar: Sekolah Tinggi

Theologia Jaffray, 2016.

Yusuf, Andriani E., Rahman Lia Putri. "Gambaran Pola Asuh Orang Tua pada Masyarakat Pesisiran Pantai." Jurnal Predicara 1, No.1 (2012): 21-33. Diakses 26 Januari 2018. https://media.neliti.com/media/publications/160191-ID-gambaran-polaasuh-orangtua-pada-masyara.pdf.

Yusuf, Syamsul. Psikologis Perkembangan Anak \& Remaja. Bandung: PT Remaja Rosdakarya, 2016.

Zubaedi. Desain Pendidikan Karakter. Jakarata: Kencana Prenada Media Group, 2012. 